\title{
EXAMINATION OF RELATED PARTY DISCLOSURE AND COMPLIANCE AMONG LISTED GHANAIAN BANKS
}

\author{
Dr. John Kwaku Mensah Mawutor \\ Dean \\ School of Graduate Studies \\ University of Professional Studies, Accra \\ P.O. Box 149 Legon, Ghana \\ E-mail: john.mensah@upsamail.edu.gh
}

\begin{abstract}
This study examined the compliance level of IAS 24, "Related Party Disclosures" of banks in Ghana and determined some firm specific characteristic that influence the level of disclosure. Using the quantitative research approach, the study was conducted on thirteen banks in Ghana constituting $56 \%$ of the entire population. Secondary data was obtained from annual reports of the banks and related published articles. The study again identified the most common type of related party transactions done by Banks in Ghana. Findings revealed that the level of compliance with IAS 24 among Banks in Ghana is relatively low. The study again found that Board Size, Company Size, Type of Auditor, Listing, and profitability has a positive influence on the level of disclosure. Findings also revealed that only Company Size is statistically significant with the level of compliance of IAS 24 among Banks in Ghana.
\end{abstract}

Keywords: Compliance, Related Party, Transactions, Banks, IAS 24, Disclosures, Failures.

JEL Classification Codes: A19, B10, B25, C10, C53.

\section{Background}

\section{INTRODUCTION}

The failure of several firms across the world has been attributed to the unavailability and nondisclosure of information regarding related party transactions (RPTs) (Rahman, 2018). Firms such as Enron were found to have used special purpose entities to manipulate income and transfer cash, guaranteed related party debt and provided extensive loans to its executive (Mayhew \& Kohlbeck, 2004). In the case of several failed financial institutions in Ghana, a recent assessment conducted by the Bank of Ghana in the banking sector found that $85 \%$ of these institutions used depositors' funds to finance personal and related party business on noncommercial basis which led to the collapse of these financial institutions (Bank of Ghana, 2019). According to Cheung, Rau, \& Stouraitis (2009), Non-disclosure of related party transactions can affect the assessment of a company's operation and eventually encourage possible conflict of interest among stakeholders of organizations.

To address these possible conflicts of interests, the International Accounting Standards Board (IASB) formulated standards (Related party transactions IAS 24) to provide vital information and data regarding entity's outstanding balances and different transactions related to 
several parties (Rahman, 2018). According to Abdul (2015), though all listed firms in Ghana were mandated to adopt IFRS in 2007, not all the listed firms after the adoption have wholly complied. A recent report by the Bank of Ghana (BoG) into the collapse of some commercial banks in Ghana has revealed some directors of the collapsed banks used a carefully spun web of related party transactions to grant huge loans to themselves and their associates without disclosing such transactions (Mustapha, 2018). This could be possibly attributed to the lack of inadequacy of comprehensive IAS compliance mechanisms in the country. Evidence on the level and extent of compliance of IAS 24 in Ghana remains limited despite its adoption several years ago (Appiah, Vitor, Mireku, \& Ahiagbah, 2016).

Studies on compliance with IFRS in Ghana are mostly focused on general compliance without comprehensively assessing individual IFRS standards compliance and the few studies on RPTs in Ghana tends to identify the factors and determinants of RPTs, not assessing their Disclosures. No prior study has conducted a comprehensive examination on the extent of compliance with IAS 24, Related Party Disclosure by banks in Ghana. In view of this phenomenon, this study assessed the extent to which Banks in Ghana comply with the disclosure requirements of International Accounting Standards (IAS 24), Related Party Disclosures.

This study has been composed into five main sections. The first section introduced the background of the study whiles the second section reviewed scholarly articles on the topic into empirically and theoretically theories. The third section of the study discussed the methodology, data analysis and the findings. Finally, the last segment of this study presented the summary of findings, recommendations and drew conclusions from the findings.

\section{LITERATURE REVIEW}

Over the decades, there have been studies on the level of compliance to IAS/IFRS, particularly on IAS 24 Related Party Disclosures. Several articles on related party transactions have been published in academic journals, however only few focused on the feature if related party transactions are properly disclosed. Some prior studies also tend to focus on the nature and extent of related party transaction based on the supposition that the disclosure on related party transactions capture the full extent of the transactions. Those studies examine either comprehensive related party transactions, for instance, the number of related party transactions (Gordon, Henry, \& Palia, 2004). Specific related party transactions such as transfer of assets, related party sales, purchases and payments. These studies did not focus on related party disclosures and level of compliance of the standard.

Gordon et al. (2004), investigated 112 firms that are publicly listed on the US stock market that disclose related transactions for the period 2000 to 2001 . Those firms operate in the manufacturing, wholesale and retail industries. Their finding indicated that on average, each firm discloses 3.9 RP transactions. The natures of these transactions are commonly real estate transactions, RP loans and RP sales.

Mayhew and Kohlbeck (2004) conducted a study on the assessment of firms that disclose related party transactions. They expressed on the view that RP transactions disclosures provide information needed by investors to discipline insider's opportunistic behavior. Following RP disclosures, they identified that investor's ability is limited to selling or refusing to buy the stocks firms that do not disclose RP transactions, or prompting ex-pose litigation against opportunistic behavior.

Barokah (2013) assessed and discussed the institutional factors that hypothetically influence RP disclosures and the extent of IAS 24 adoption in selected Asian- pacific countries, a 
sample of 582 listed companies were used for this study. She found that RP transactions are common across Asian- Pacific countries, with RP loans been the common type of transaction. She also found that other factors such as strength of enforcement by accounting regulatory bodies, the control for corruption, the protection of minority shareholders against self - dealing actions impacts RP disclosure transparency. Adequate disclosure of sensitive information in a financial statement is paramount to the protection of investors' interest (Tanwar, Vaish, \& Rao, 2020; Waleru \& Beauty, 2018; Bidabad, 2019).

Arshad, Darus, and Othman (2009), investigated the effects of IFRS adopted standard, board members with accounting profession affiliations, board interlocks, family members, government- ownership and the independent non-executive directors on the extent of RP transactions in two disclosure periods 2002 and 2007. They used the annual reports of 144 Malaysian listed companies to conduct the study. They measured related party disclosure as the set/aggregate number of words related to RP disclosures in the annual reports. Their findings indicated that the extent of RP discloses has a positive relationship with professional affiliation and company size, but they did not find any influence of the other variables (i.e. Family ownership and independent of non-executive directors) on the extent of RP disclosures. In his study Rahman (2018), he assessed the present status of related party disclosure and practice level of IAS 24, Related Party Disclosures in annual reports by 10 listed banks in Bangladesh. He found that there is poor application and compliance of IAS 24 among listed banks in Bangladesh.

Agyei-Mensah (2012), also conducted a study to investigate the influence of firmspecific characteristics such as firm size, profitability, debt equity ratio, liquidity and audit firm size on voluntary disclosures of financial information and found that profitability is positively related to the disclosure level, while debt equity ratio, liquidity, firm size and audit firm size were insignificantly related to disclosure level of the banks. Bakkeri \& Ali (2020) also found other regulatory variables as critical factors that determine the profitability of banks. According to Bidabad and Allahyarifard (2019), adequate disclosure of firms' financial statement has positive impact on the profitability of firms.

From the above reviews it is evidenced that much of the studies on IAS 24 were done in foreign countries. Little has been done in Ghana concerning Related Party Disclosures, most of which focused on the implications of related party transactions but not their Disclosures or the compliance level of Related Party Disclosures (IAS 24). It is therefore prudent for the researchers to assess the compliance level of this standard.

\section{METHODOLOGY}

The study adopted the quantitative research approach to examine the relationship between dependent and independent variables. Data required for this study were collected from secondary sources. The targeted population for the study was Banking Financial Institutions in Ghana. There are currently twenty-three (23) banking institutions in Ghana.

The sampling technique used for this study was judgmental sampling. Judgmental sampling is the sampling technique use by a researcher to exercise judgment to select cases that enable the researcher achieves the objectives of the study and more so to answer the research questions. Out of the twenty Banks in, thirteen of them were used for the study which constitutes $56.5 \%$ of the targeted population. The researchers decided to conduct the study on thirteen out of the twenty-three banks in Ghana due to limited time factor, availability of data and also because of the researchers believe that thirteen out of twenty-three is illustrative enough.

3.2 Dependent and Independent variables 
The dependent variable used for this study is the extent of compliance to IAS 24, Related party Disclosures by Banks in Ghana. On the other hand, the independent variables used to explain the dependent variable are Board size, Company size, Type of Auditor, Profitability, listing status and ownership concentration. Choosing these variables is informed by prior disclosure literature as they were identified to be related to disclosure. The relationship between the independent variable and dependent variable is the basis of most statistical test, which establishes whether there is a significant relationship between the two types of variables. The results of these tests allow the researcher to accept or reject the null hypothesis, and draw conclusions (Shuttleworth, 2008).

To assess the influence of the independent variables on dependent variable the following hypothesis was developed.

Ho: Board size is not significantly associated with the level of RP disclosures of banks in Ghana.

Ho: Company size is not statistically significant with the level of RP disclosures of banks in Ghana.

Ho: Type of auditor does not have a significant influence on the level of RP disclosures of banks in Ghana.

Ho: Profitability does not have a significant influence with the level of RP disclosures of banks in Ghana.

Ho: listing status does not have a significant influence on the level of RP disclosures of banks in Ghana.

Ho: Ownership concentrations do not significantly influence the level of RP disclosures of banks in Ghana.

\section{DATA ANALYSIS}

To assess the extent of compliance of IAS 24, Related Party Disclosures by listed banks, a selfstructured compliance checklist was developed by the researchers in accordance to the disclosure requirements mandated by IAS 24. To validate the checklist, it was presented to a proficient auditor to crisscross the comprehensiveness and applicability to IAS 24. In order to measure the relationship between variables; Correlation, Regression Analysis Model and Descriptive Analysis was employed. In describing the association between two or more variables in terms of magnitude and direction, correlation was used. The regression analysis allowed modeling the relationship between a dependent variable and one or more independent variables of numerical data (Stuart \& Headlam).

\section{MODELS DEVELOPMENT}

In order to measure the level of disclosure of IAS 24, a disclosure index was employed. This was used as the dependent variable and the firm specific characteristics (board size, company size, type of auditor, profitability, Listing status and Ownership concentration) as independent variables. The disclosure index is in the functional formula:

$\mathrm{DI}=\frac{\text { Number of items disclosed in the Annual Reports }}{\text { Total Number of disclosed items }}$

Where,

- $\quad \mathrm{DI}=$ Disclosure Index 
- $\quad \mathrm{DI}=\sum \mathrm{di}$

- $\mathrm{d}=1$ if item is disclosed

- $\mathrm{i}=1 \quad 0=$ if item is not disclosed

- $\mathrm{n}=$ number of items

To estimate the relationship between the dependent variable and the independent variables the following regression model and equation was applied.

DI = $\mathrm{f}$ (Board Size, Company Size, Type of Auditor, Profitability (ROE), Listing status and Ownership concentration)

To measure the relationship between variables the following equation was developed.

$\mathrm{DI}_{\mathrm{it}}=\beta 0+\beta 1 \mathrm{BSIZE}_{\mathrm{it}}+\beta 2 \mathrm{CSIZE}+\beta 3 \mathrm{AUD}_{\mathrm{it}}+\beta 4 \mathrm{ROE}_{\mathrm{it}}+\beta 5 \mathrm{LIST}_{\mathrm{it}}+\beta 5 \mathrm{OWN}_{\mathrm{it}}+\mathrm{e}$

Where,

- $\mathrm{DI}=$ Disclosure index

- $\beta 0=$ the intercept

- BSIZE = Board Size (the number of directors on the board)

- CSIZE = Company Size (the banks total asset at year end)

- $\mathrm{AUD}=$ Type of Auditor (dummy variable 1 if bank is audited by Big 4 (KPMG, Deloitte, PWC, Ernst and Young) and 0 if otherwise)

- ROE = Profitability of Bank Measured in Return to Equity (Net profit/ Total shareholders' equity)

- $\quad$ LIST = Listing Status: dummy variable 1 if bank is listed on GSE and 0 if not listed)

- $\mathrm{OWN}=$ Largest Shareholder percentage

- $\mathrm{E}=$ the error term

\section{ANALYSIS AND DISCLOSURE REQUIREMENTS OF IAS 24, RELATED PARTY DISCLOSURES.}

Inference to research question one (RQ1) captured in chapter 2, on the disclosure requirements of IAS 24, Table 1 identified these requirements as per stated by the IASB. Data obtained after surveying the annual reports of thirteen banks in Ghana for the period of ten years indicated the following status of IAS 24, Related Party Disclosures by banks in Ghana.

1. A reporting entity shall disclose the name of its parent company; referring to Table 1, the study found that $66 \%$ of the sample banks disclosed the name of their parent company.

2. The entity shall disclose the name of its ultimate controlling party if different to its parent; it can be seen from Table 1 that $17 \%$ of the sample banks the name of its ultimate controlling party different to its parents.

3. Disclose the name of the next most senior parent (where neither the entity's parent nor the ultimate controlling party produces consolidated financial statements available for public use); from the Table 1, none (0\%) of the sample banks disclosed the name of the most senior parent that is neither the entity parent nor the ultimate controlling party produces consolidated financial statement available for public use. 
4. Disclose key management personnel compensation in total for each of the following categories:

(a) Short-term employee benefits; the Table 1 below indicated that $72 \%$ of the sample banks disclosed the key management compensation for short- term employee benefit.

(b) Post-employment benefits; it can be seen in the Table 1 that $61 \%$ of the selected banks disclosed post- employment benefits for key management compensation.

(c) Other long term benefits; from the Table 1, this item has been disclosed by $3 \%$ of the selected banks.

(d) Termination benefit; has been disclosed by $26 \%$ of the sample banks.

(e) Share based payment; referring to Table 1, this item was disclosed by $26 \%$ of the selected banks.

5. Disclose the nature, amount, and outstanding balances of related party transactions by separate categories for each of the following:

(a) Parent company: referring to the Table 1,37\% of the sample banks disclosed transactions with parent companies.

(b) Entities with joint control or significant influence over the entity; none of the sample banks disclosed this item

(c) Subsidiaries; $44 \%$ of the sample banks disclosed transactions with subsidiaries (Table 1)

(d) Associates; $42 \%$ of the selected banks disclosed transactions with associates.

(e) Joint venture in with the entity is a venture; none of the selected banks over the ten years period disclosed transactions with joint ventures.

(f) Key management personnel of the entity or its parent; $92 \%$ of the selected banks disclosed transactions with key management personnel.

(g) Other related parties; $53 \%$ of the sample banks disclosed transactions with other related parties (Table 1)

6. Government-related entity taken exemption where the government related entity applies the exemption in paragraph 25 of IAS 24 (2009)

(a) The reporting entity shall disclose the name of the government; from Table 1, on average $17 \%$ of the selected banks for the ten years period disclosed information on government related parties.

(b) Disclose the nature of its relationship with the reporting entity (i.e. control, joint control or significant influence); in reference to Table 1, 17\% of the selected banks disclosed the nature of government related relationships.

c) Disclose the nature of and amount of each individually significant transaction in sufficient detail to enable users of the entity's statements to understand the effect of related party transactions on its financial statement; from Table 1, 13\% of the selected banks disclosed transactions with government related parties.

d) Disclose other transactions that are collectively, but not individually, significant a qualitative or quantitative indication of their extent; none of the banks disclosed this item (Table 1) 
Table 1. Frequency of disclosure of IAS 24, Related party Disclosures

\begin{tabular}{|c|c|c|c|c|}
\hline & Disclosure requirement under IAS 24 & $\begin{array}{l}\text { Sample } \\
\text { observation }\end{array}$ & $\begin{array}{l}\text { Disclosure } \\
\text { level }\end{array}$ & $\begin{array}{l}\text { Disclosure } \\
\text { percentage }\end{array}$ \\
\hline 1 & $\begin{array}{l}\text { A reporting entity shall disclose the } \\
\text { name of its parent company }\end{array}$ & 119 & 79 & $66 \%$ \\
\hline 2 & $\begin{array}{l}\text { The entity shall disclose the name of its } \\
\text { ultimate controlling party if different to } \\
\text { its parent }\end{array}$ & 119 & 20 & $17 \%$ \\
\hline 3 & $\begin{array}{l}\text { Disclose the name of the next most } \\
\text { senior parent (where neither the entity's } \\
\text { parent nor the ultimate controlling } \\
\text { party produces consolidated financial } \\
\text { statements available for public use). }\end{array}$ & 119 & 0 & $0 \%$ \\
\hline \multirow[t]{6}{*}{4} & $\begin{array}{l}\text { Disclose key management personnel } \\
\text { compensation in total for each of the } \\
\text { following categories: }\end{array}$ & & & \\
\hline & (i) short-term employee benefits; & 119 & 86 & $72 \%$ \\
\hline & (ii) post-employment benefits & 119 & 72 & $61 \%$ \\
\hline & (iii)other long-term benefit & 119 & 3 & $3 \%$ \\
\hline & (iv)termination benefit & 119 & 31 & $26 \%$ \\
\hline & (v)share base payment & 119 & 31 & $26 \%$ \\
\hline \multirow[t]{8}{*}{5} & $\begin{array}{l}\text { Disclose the nature, amount and } \\
\text { outstanding balances of related party } \\
\text { transactions by separate categories for } \\
\text { each of the following: }\end{array}$ & & & \\
\hline & (a) The parent & 119 & 44 & $37 \%$ \\
\hline & $\begin{array}{l}\text { (b) entities with joint control or } \\
\text { significant influence over the entity }\end{array}$ & 119 & 0 & $0 \%$ \\
\hline & (c) subsidiaries & 119 & 52 & $44 \%$ \\
\hline & (d) associates & 119 & 50 & $42 \%$ \\
\hline & $\begin{array}{l}\text { (e) (e) joint ventures in which the } \\
\text { entity is a venture }\end{array}$ & 119 & 0 & $0 \%$ \\
\hline & $\begin{array}{l}\text { (f) key management personnel of the } \\
\text { entity or its parent; and }\end{array}$ & 119 & 105 & $92 \%$ \\
\hline & (g) ) other related parties & 119 & 63 & $53 \%$ \\
\hline \multirow[t]{2}{*}{6} & $\begin{array}{l}\text { Government-related entity taken } \\
\text { exemption where the government } \\
\text { related entity applies the exemption in } \\
\text { paragraph } 25 \text { of IAS } 24(2009) \text {; }\end{array}$ & & & \\
\hline & $\begin{array}{l}\text { (a) The reporting entity shall disclose } \\
\text { the name of the government. }\end{array}$ & 119 & 17 & $14 \%$ \\
\hline
\end{tabular}




\begin{tabular}{|c|c|c|c|}
\hline $\begin{array}{l}\text { (b) ) Disclose the nature of its } \\
\text { relationship with the reporting entity } \\
\text { (i.e. control, joint control or significant } \\
\text { influence); }\end{array}$ & 119 & 17 & $14 \%$ \\
\hline $\begin{array}{l}\text { c) Disclose the nature of and amount of } \\
\text { each individually significant } \\
\text { transaction in sufficient detail to enable } \\
\text { users of the entity's statements to } \\
\text { understand the effect of related party } \\
\text { transactions on its financial statement. }\end{array}$ & 119 & 13 & $11 \%$ \\
\hline $\begin{array}{l}\text { d) Disclose other transactions that are } \\
\text { collectively, but not individually, } \\
\text { significant a qualitative or quantitative } \\
\text { indication of their extent. }\end{array}$ & 119 & 0 & $0 \%$ \\
\hline
\end{tabular}

Source: Research results

\section{The Nature and Extent of Related Party Transactions by Banks in Ghana}

Answering the second research question (RQ2), findings from the survey of yearly annual reports of the banks and other published related articles indicated that the most common related party transactions by banks in Ghana are related party loans. These related party loans include loans to directors, executives and other employees other than directors. Lending to insiders may become a significant source of financial risk to the banks as most of these loans are granted at interest rates different from market rates.

\section{Dependent Variable}

To the research question (RQ3), what is the disclosure level of IAS 24 in banks in Ghana; data collected from yearly annual reports of thirteen banks for a period of ten years, inference to Table 2 indicated that the dependent variable; the extent of compliance with IAS 24, Related Party Disclosures had an average score of 30.5\%. This implies that the extent of IAS 24 disclosures among banks in Ghana is moderately low. The findings also indicated a maximum compliance level of $63 \%$ among some banks and a minimum compliance level of $5 \%$.

Table 2. Descriptive analysis of disclosure compliance of IAS 24

\begin{tabular}{|l|l|l|l|}
\hline Mean & Standard deviation & Maximum & Minimum \\
\hline $30.5 \%$ & $13 \%$ & $63 \%$ & $5 \%$ \\
\hline
\end{tabular}

Source: Research results

\section{Disclosure Compliance of IAS 24 by Banks}

From the survey of yearly annual reports of the selected banks, compliance on bank basis found the following results, inference from Figure 1 shows that Standard Chartered Bank had the highest disclosure score of $49 \%$ followed by CAL Bank with a score of $48 \%$ and Ghana Commercial Bank (46\%). National Investment Bank had the minimum score of $18 \%$. 


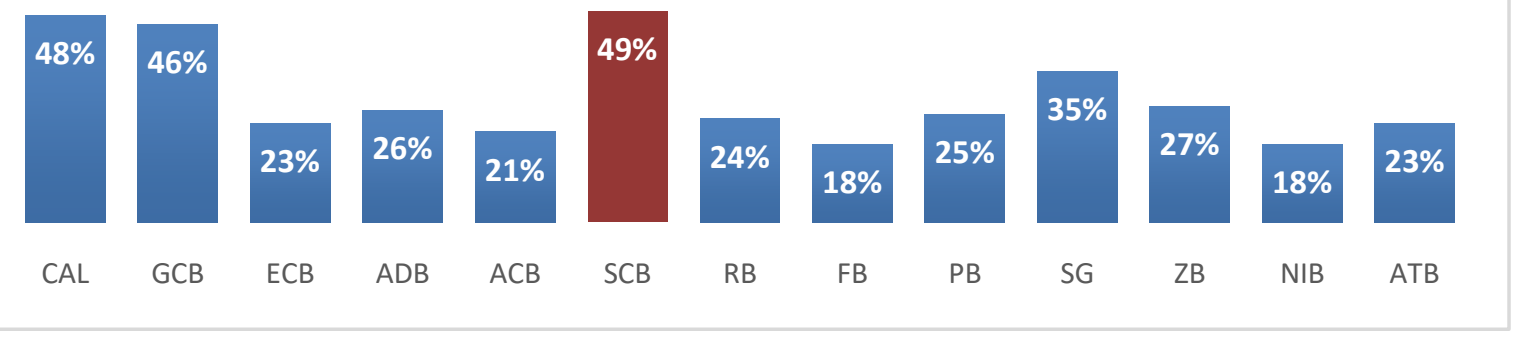

Figure 1. Disclosure compliance of IAS 24 by banks Source: Research results

Table 3. Range of disclosure items with IAS 24, Related Party Disclosures

\begin{tabular}{|c|c|c|c|c|c|c|c|c|c|c|c|c|c|c|}
\hline & $\begin{array}{c}\text { CA } \\
\text { L }\end{array}$ & GBC & $\begin{array}{c}\text { EC } \\
\text { B }\end{array}$ & $\begin{array}{c}\text { AD } \\
\text { B }\end{array}$ & $\begin{array}{c}\text { AC } \\
\text { B }\end{array}$ & $\begin{array}{c}\text { SC } \\
\text { B }\end{array}$ & RB & FB & PB & SG & ZB & $\begin{array}{c}\text { NI } \\
\text { B }\end{array}$ & $\begin{array}{c}\text { AT } \\
\text { B }\end{array}$ & Total \\
\hline TDR per yr & 19 & 19 & 19 & 19 & 19 & 19 & 19 & 19 & 19 & 19 & 19 & 19 & 19 & \\
\hline OBS(yrs) & 10 & 10 & 10 & 10 & 8 & 10 & 10 & 10 & 10 & 10 & 10 & 5 & 5 & 118 \\
\hline TDR (10yrs) & 190 & 190 & 190 & 190 & 152 & 190 & 190 & 190 & 190 & 190 & 190 & 95 & 95 & 2242 \\
\hline Total & 91 & 90 & 43 & 50 & 32 & 94 & 46 & 35 & 47 & 66 & 52 & 17 & 22 & 685 \\
$\begin{array}{c}\text { Disclosed } \\
\text { items }\end{array}$ & & & & & & & & & & & & & & \\
\hline $\begin{array}{c}\text { Disclosure } \\
\text { index }\end{array}$ & 0.48 & 0.46 & $\begin{array}{c}0.2 \\
3\end{array}$ & 0.26 & 0.21 & 0.49 & $\begin{array}{c}0.2 \\
4\end{array}$ & $\begin{array}{c}0.1 \\
8\end{array}$ & $\begin{array}{c}0.2 \\
5\end{array}$ & $\begin{array}{c}0.3 \\
5\end{array}$ & $\begin{array}{c}0.2 \\
7\end{array}$ & $\begin{array}{c}0.1 \\
8\end{array}$ & 0.23 & 0.305 \\
\hline
\end{tabular}

Source: Research results

\section{Independent Variables}

This section answers the research question (RQ4) and discusses the descriptive analysis of the firm specific characteristics that influence disclosure compliance of IAS 24; represented as the independent variables: Board size, company size, profitability (ROE), Ownership concentration, Listing Status and Type of auditor.

Table 4. Descriptive analysis of independent variables

\begin{tabular}{|l|l|l|l|l|l|}
\hline & N & Mean & Maximum & Minimum & Std. deviation \\
\hline BSIZE & 118 & 9.39 & 15 & 6 & 1.612 \\
\hline CSIZE & 118 & $2.46 \mathrm{E}+10$ & $1.06 \mathrm{E}+10$ & 1324350 & $2.13 \mathrm{E}+09$ \\
\hline ROE & 118 & 0.22 & 0.57 & -0.27 & 0.129 \\
\hline OWN & 103 & 0.48 & 0.93 & 0.21 & 0.189 \\
\hline
\end{tabular}

Source: Research results

\section{Regression Analysis and Hypothesis Testing}

The last research question (RQ5) aims to investigate the influence of the firm specific characteristics on the level of compliance. This section discusses the regression results of the model developed in chapter 3 to test the study hypothesis. Random effect estimation was used to generate the regression results after a Hausman test conducted indicated a P $>0.05$, which implies that Random effect regression model is the appropriate method for generating the regression results. Table 4 shows the results of the model using the independent variables to explain the 
level of compliance. The results also indicated that the model used for the analysis is statistically significant $($ Prob $($ F-stat $)=0.00<$ Alpha $=0.05)$. It can be seen from Table 5 that the R-squared is 0.16 and the Adjusted R-squared of is 0.1 , this implies that $10 \%$ of the variations in the dependent variable is explained by the dependent variables.

Table 5. Regression results

\begin{tabular}{|c|c|c|c|c|}
\hline \multicolumn{5}{|c|}{$\begin{array}{l}\text { Dependent Variable: DI } \\
\text { Method: Panel EGLS (Cross-section random effects) }\end{array}$} \\
\hline Variable & Coefficient & $\begin{array}{l}\text { Std. } \\
\text { Error }\end{array}$ & $\begin{array}{c}\text { t- } \\
\text { Statistic }\end{array}$ & Prob. \\
\hline $\mathrm{C}$ & 0.088877 & 0.113592 & 0.78242 & 0.4359 \\
\hline BSIZE & 0.011252 & 0.007254 & 1.551144 & 0.1242 \\
\hline CSIZE & $9.97 \mathrm{E}-12$ & $4.57 \mathrm{E}-12$ & 2.182805 & 0.0315 \\
\hline AUD & 0.056791 & 0.055437 & 1.024416 & 0.3082 \\
\hline $\mathrm{ROE}$ & 0.033755 & 0.077444 & 0.435864 & 0.6639 \\
\hline LIST & 0.057369 & 0.040402 & 1.419969 & 0.1589 \\
\hline OWN & -0.028606 & 0.089001 & -0.32141 & 0.7486 \\
\hline \multicolumn{5}{|l|}{ Observations: 103} \\
\hline R-squared & 0.16207 & \multicolumn{2}{|c|}{ Mean dependent var } & 0.0655 \\
\hline Adjusted R-squared & 0.1097 & \multicolumn{2}{|c|}{ S.D. dependent var } & 0.07236 \\
\hline S.E. of regression & 0.069029 & \multicolumn{2}{|c|}{ Sum squared resid } & 0.45744 \\
\hline F-statistic & 3.094678 & \multicolumn{2}{|c|}{ Durbin-Watson stat } & 1.18342 \\
\hline Prob(F-statistic) & 0.008174 & & & \\
\hline
\end{tabular}

Source: E-views

\section{Hypothesis Testing}

The regression result generated the model shown below.

$\mathrm{DI}=0.88877+\quad 0.011252 \mathrm{BSIZE}+\quad 9.97 \mathrm{E}-12 \mathrm{CSIZE}+\quad 0.056791 \mathrm{AUD} \quad+0.033755 \mathrm{ROE}$ +0.057369 LIST $-0.028606 \mathrm{OWN}$.

Hypothesis one (H1) predicts that Board size is not significantly associated with the level of RP disclosures, in reference to Table 5 Board size coefficient shows a positive relationship with the level of RP but does not support at a significant level of 0.05 ( $\mathrm{P}$ value $0.12>$ alpha 0.05 ), in view of this the hypothesis one (H1) is accepted.

Hypothesis two (H2) predicts that Company size is not significantly associated with the compliance level of RP disclosures, contrary to Table 5 Company size has a positive statistically significant relationship with the level of RP disclosures $(\mathrm{P}=0.03<$ Alpha 0.05$)$. This implies that a unit increase in the size of the company will increase compliance level by 9.9. In view of this, hypothesis two (H2) is rejected.

Hypothesis three (H3) predicts that Type of auditor do not have a significant influence on the level of RP disclosures, Table 5 indicates that Type of auditor has a positive relationship with the level of compliance but proves statistically insignificant, hence hypothesis three $(\mathrm{H} 3)$ is accepted. 
Hypothesis four (H4) predicts that profitability (ROE) do not have a significant relationship with the level of compliance, in reference to Table 5, ROE shows a positive relationship with the level of compliance but is statistically insignificant $(\mathrm{P}=0.30>$ Alpha=0.05), hence the null hypothesis four (H4) is accepted.

Hypothesis five (H5) states that Listing Status is not significantly associated with the level of disclosure compliance, it can be seen in Table 5 that it is statistically insignificant $(\mathrm{P}=0.15>$ Alpha $=0.05)$, hence hypothesis five (H5) is accepted.

Hypothesis six (H6) predicts that Ownership concentration do not have a significant relationship with the level of IAS 24 compliance, in reference to Table 5, Ownership concentration is negatively associated with the level of compliance and does not support at a significant level $(\mathrm{P}=$ $0.74>$ Alpha=0.05). Hence hypothesis six (H3) is accepted.

\section{SUMMARY OF FINDINGS}

The main objective of this research is to assess the level of compliance of Related Party Disclosure (IAS 24) by Banks in Ghana. The main objective came along with five specific objectives, research questions and hypothesis. The study employed descriptive analysis to capture the mean, maximum, minimum and standard deviation of the dependent and independents variables. The findings were presented in tables and figures to provide clarity to the findings. A panel data regression was conducted using E-views software which enabled the hypothesis testing of the study. The study surveyed on 118 annual reports of banks for a period of ten years.

On the main objective of the study, findings revealed that compliance level of IAS 24, Related Party Disclosures had an average score of $30.5 \%$ which implies a low level of compliance by the selected banks in Ghana. The results also indicate a maximum compliance level of $58 \%$ and a minimum compliance level of 5\%. The study also revealed that Standard Chartered Bank Limited had the highest compliance level of $49 \%$, followed by CAL Bank Limited (48\%) and Ghana Commercial Bank Limited with a score of $46 \%$. Furthermore, the study again identified that Fidelity Bank Ghana and National Investment Bank had the lowest compliance level of $18 \%$.

In relation to the nature and extent of RP transactions in Ghana, findings revealed that the most common related party transactions conducted by banks in Ghana is related party loans. Thus loans to directors, executives and others staffs other than directors.

Results from the self-contracted contracted checklist indicated that the most frequent disclosures of IAS 24 by banks in Ghana are transactions with key management personnel followed by short term compensation to key management personnel and the disclosure of company parent name. Transactions with joint ventures are the least disclosed item.

The panel data regression conducted to identify the relationship between the dependent and independent variable found that Board size, Type of auditor, Listing status and ROE has a positive insignificant relationship with the level of compliance while Company size had statistically significant positive relationship with the level of disclosure compliance. Moreover Ownership concentration had a negative relationship with the level of IAS 24 compliance and was insignificant.

\section{CONCLUSION}

It can be deduced from the findings of study that compliance level of IAS 24 by banks is poor in Ghana. Related party transactions if not properly disclosed can lead to fraudulent activities and if 
it continues can pose a financial risk to the company. Due to the desire to satisfy statutory rules and regulations, the banks do not comprehensively provide adequate information as prescribed by the standard IAS 24 and therefore completely ignoring the detailed requirement of the standard. Out of the six firm specific characteristics that were identified to influence compliance level of the standard (IAS 24), only Company size had a statistically significant impact on the level of compliance. The study also identified that all the firm specific characteristics has a positive relationship with the level of RP disclosures except Ownership concentration that has a negative relationship with RP disclosures. Based on the data collected from the selected banks for the study, it can be concluded that Banks in Ghana over the ten year period had an average score of $30.5 \%$ approximately $31 \%$ compliance with IAS 24, Related Party Disclosures.

Even though the findings addressed the research questions, the study had some limitations. The study initially targeted 130 annual reports from thirteen banks but due to the failure of some banks to consistently publish their annual reports, the researchers obtained only 118 annual reports. One of the independent variables used for the study; ownership concentration were not included at all in the annual reports of one of the selected banks over the entire period of study. This same variable was inconsistently disclosed in the annual reports of some banks included in the sample. These left the researchers with no other choice than to run the analysis of the research on unbalanced data.

\section{REFERENCES}

Abdul, M. (2015). Corporate Compliance with International Financial Reporting Standard of Listed Banking Financial Institutions in Ghana.

Arshad, R., Darus, F., \& Othman, S. (2009). Institutional Pressure, Corporate Governance Structure and Related Party Disclosure: Evidence from Enhanced Disclosure Regimes. The Business Review, 13(2), 186-193.

Appiah, K. O., Vitor, D. A., Mireku, K., \& Ahiagbah, C. (2016). Compliance with IFRS : The case of Listed firms in Ghana. Journal of Financial Reporting and Accounting, 131-156.

Agyei-Mensah, B. K. (2012). Association between firm-specific characteristics and levels of disclosure of financial information of rural banks in the Ashanti region of Ghana. Journal of Applied Finance and Banking, 2(1), 69.

Barokah, Z. (2013). An analysis of corporate related-party disclosure in the Asia-Pacific region (Doctoral dissertation, Queensland University of Technology).

Bakkeri, A., \& Ali, A. B. (2020). PROFITABILITY OF ISLAMIC BANKS: A PANEL DATA ANALYSIS. Indian Journal of Finance and Banking, 4(3), 26-38. https://doi.org/10.46281/ijfb.v4i3.811

Bidabad, B., \& Allahyarifard, M. (2019). The Executive Mechanism of Rastin Profit and Loss Sharing (PLS) Banking. Indian Journal of Finance and Banking, 3(1), 23-39. https://doi.org/10.46281/ijfb.v3i1.308

Bidabad, B. (2019). Insurance Products in Rastin Profit and Loss Sharing Banking. Indian Journal of Finance and Banking, 3(1), 40-54. https://doi.org/10.46281/ijfb.v3i1.344 
Bank of Ghana. (2019). Notice of Revocation of Licences of Insolvent Savings and Loans Companies and Finance Houses. Accra: Bank Of Ghana.

Cheung, Y., Rau, R., \& Stouraitis, A. (2009). Buy high, Sell low: How listed firms assets transfer is related party transaction. Journal of Banking and Finance, 914-924.

Gordon, E., Henry , E., \& Palia, D. (2004). Related Party Transactions and Corporate Governance. Emerald, 1-27.

Mayhew, B., \& Kohlbeck, S. (2004). Related party transactions. Working paper. University of Wisconsin.

Mustapha, S. (2018). Directors of the Collapsed banks granted huge loans to themselves. Accra: Daily Graphic Business.

Rahman, M. (2018). Compliance of IAS 24, Related Party Disclosure in Listed Commercial Banks: Evidence from Bangladesh. Journal of Banking and Finance Management, 19-27.

Shuttleworth, M. (2008, july 4). Dependent Variable. Retrieved october 17, 2014, from explorable.com: https://explorables.com/dependent-variable

Tanwar, J., Vaish, A. K., \& Rao, N. V. M. (2020). MATHEMATICAL MODELING OF ASSET LIABILITY MANAGEMENT IN BANKS USING GOAL PROGRAMMING AND AHP. Indian Journal of Finance and Banking, 4(4), 1-19. https://doi.org/10.46281/ijfb.v4i4.899

Waleru, A. H., \& Beauty, O. (2018). Determinants of Commercial Banks Credit to the Domestic Economy in Nigeria: Examinations of Dynamics Principles. Indian Journal of Finance and Banking, 2(2), 26-41. https://doi.org/10.46281/ijfb.v2i2.96

\section{Copyrights}

Copyright for this article is retained by the author(s), with first publication rights granted to the journal. This is an open-access article distributed under the terms and conditions of the Creative Commons Attribution license (http://creativecommons.org/licenses/by/4.0/) 